\title{
RANCANG BANGUN APLIKASI REMINDER MAINTENANCE ASET BERBASIS WEB
}

\author{
Yordias F. Rambing ${ }^{1}$, Liza Wikarsa ${ }^{2}$, Junaidy B. Sanger ${ }^{3}$ \\ Program Studi Teknik Informatika ${ }^{123}$ \\ Universitas Katolik De La Salle Manado ${ }^{123}$ \\ e-mail:12013009@unikadelasalle.ac.id ${ }^{1}$, lwikarsa@unikadelasalle.ac.id², \\ jsanger@unikadelasalle.ac.id ${ }^{3}$
}

\begin{abstract}
This research aims to build a web-based applications for maintenance asset reminder. The method used to build this system is Rapid Application Development (RAD), which consists of Requirements Planning, User Design, Construction, and Testing. Application Development using PHP and MySQL. The results showed that the application built easy to use and can help users.
\end{abstract}

Keywords: Web-based applications, Maintenance asset reminder, RAD, PHP, MySQL

\section{A. PENDAHULUAN}

PT. Gapura Utarindo International merupakan perusahaan yang bergerak dalam bidang perhotelan, yang mengelola Hotel Gran Puri Manado sejak tahun 2001. Perusahaan ini menyediakan jasa penginapan, fasilitas olahraga, hiburan dan restoran. Dalam pengoperasiannya, perusahaan ini dibagi atas beberapa bagian, diantaranya bagian Sales, bagian IT, bagian Purchasing, bagian Administration, bagian Engineering, bagian Housekeeper, bagian Personel dan bagian food and beverage.

Bagian Administration bertanggung jawab untuk menangani beberapa proses seperti menangani pendaftaran supplier, menangani pembayaran aset, dan monitoring maintenance aset. Proses yang dijadikan studi kasus yaitu proses monitoring maintenance aset, yang diawali dari menentukan aset apa yang perlu dilakukan maintenance, dan memberikan tugas ke teknisi untuk melakukan maintenance. Teknisi memberikan laporan hasil maintenance, kemudian laporan dicatat di buku maintenance. Terdapat beberapa masalah yang sering terjadi pada proses ini seperti karyawan kesulitan dalam menentukan aset apa yang harus dimaintenance karena untuk menentukannya karyawan harus melihat tanggal maintenance terakhir dari buku maintenance kemudian menambahkan lama jangka waktu untuk melakukan maintenance untuk mendapatkan tanggal maintenance dari aset tersebut. Penyimpanan laporan yang masih dalam bentuk kertas, membuat karyawan kesulitan dalam melakukan pencarian informasi keadaan aset atau untuk mencari history maintenance aset tertentu. Selain itu, jika ada aset yang terlewat untuk dimaintenance karyawan sulit untuk mengetahuinya jadi untuk memastikan tidak ada aset yang terlewat untuk dimaintenance karyawan membutuhkan reminder berupa SMS yang bisa memberikan informasi ke karyawan setiap hari.

Tujuan dari penelitian ini adalah untuk membangun Aplikasi Reminder Maintenance Aset berbasis Web yang dapat memudahkan PT. Gapura Utarindo 
International, khususnya bagian Administration dalam menangani proses pendataan, monitoring maintenance, dan pelaporan aset.

\section{B. TINJAUAN PUSTAKA}

Aset

Menurut Nurhayati (2015), aset adalah sumber daya yang dikendalikan oleh perusahaan sebagai akibat transaksi masa lalu dan masih bermanfaat di masa mendatang. Aset memiliki ciri-ciri yaitu:

1. Sumber daya yang memiliki nilai ekonomi, artinya bisa dijual dan bernilai

2. Dikuasai atau dikendalikan oleh perusahaan

Dewa (2012) juga menjelaskan, aset adalah barang atau sesuatu yang kita miliki yang terus menerus menghasilkan uang bagi kita sebagai pemilik.

\section{Reminder}

Menurut Syamsuri (2010), reminder adalah sesuatu yang membuat seseorang ingat, biasanya pada waktu yang telah ditentukan. Reminder biasanya berkaitan dengan alarm. Alarm pada umumnya untuk memberi peringatan kepada pengguna bahwa ada suatu kegiatan pada waktu yang telah ditentukan sebelum alarm itu berbunyi.

\section{Maintenance}

Menurut Thompson (2013), "Maintenance is the act of keeping something in a state of good operating condition”. Ada beberapa jenis maintenance menurut Mahler dan Sabirin (2008), yaitu: Breakdown maintenance, Preventive and Predictive maintenance, dan Proactive maintenance.

\section{Website}

Menurut Ginanjar (2014), website adalah rangkaian atau sejumlah halaman di internet yang memiliki topik saling terkait untuk mempresentasikan suatu informasi. Ada 3 (tiga) jenis website, yaitu website statis, website interaktif sederhana, dan sistem basis data berbasis web yang kompleks.

\section{PHP}

Menurut Anhar (2010), PHP singkatan dari Hypertext Preprocessor yaitu bahasa pemrograman web server-side yang bersifat open source. PHP merupakan script yang terintegrasi dengan HTML dan berada pada server (server side HTML embedded scripting).

\section{Basis Data}

Menurut Junindar (2008), Database (basis data) merupakan kumpulan data yang saling berhubungan satu dengan lainnya yang tersimpan di perangkat keras komputer dan diperlukan suatu perangkat lunak untuk memanipulasi basis data tersebut.

Salah satu teknologi yang digunakan untuk mengimplementasi suatu basis data itu adalah MySQL. MySQL adalah sebuah perangkat lunak sistem manajemen basis data SQL (Database Management System) atau DBMS yang multithread multi-user, dengan sekitar 6 juta instalasi di seluruh dunia (Solichin, 2010).

\section{Kakas Pemodelan}

Kakas yang digunakan untuk melakukan analisis dan perancangan sistem yang baru menggunakan UML (Unified Modeling Language). Beberapa diagram yang digunakan yaitu Use Case Diagram, Activity Diagram, dan Class Diagram.

\section{SMS}

SMS merupakan fasilitas standar dari sistem telepon bergerak digital. Fasilitas ini digunakan untuk mengirim dan menerima pesan dalam bentuk teks ke dan dari sebuah 
ponsel (Ukar, 2006). Untuk membuat SMS gateway digunakan perangkat lunak yang bernama Gammu. Gammu merupakan perangkat lunak yang mengontrol modem USB atau telepon seluler. Gammu bisa mengirim atau menerima pesan, melakukan panggilan, melihat kontak dan lainnya (selama perangkat tersebut didukung oleh Gammu).

\section{METODE}

Metode yang digunakan untuk membangun Aplikasi Reminder Maintenance Berbasis Web ini adalah Rapid Application Development (RAD). Menurut Setiawan et al. (2011), RAD adalah model proses pembangunan perangkat lunak yang berfokus pada membangun aplikasi dalam waktu yang singkat yang tergolong dalam teknik incremental (bertingkat). Metode ini menggunakan metode iteratif atau berulang dan bersifat dinamis sehingga terbuka akan adanya perubahan yang terjadi selama pengembangan sistem.

RAD ini terdiri dari empat fase utama, yakni Requirements Planning, User Design, Construction, dan Testing and Turn Over (Sawena et al. 2014).

\section{HASIL DAN PEMBAHASAN}

Use case diagram sistem yang sedang berjalan yang ditunjukkan pada Gambar 1 mendeskripsikan kegiatan mengecek history maintenance, mengalokasikan pekerjaan maintenance, dan membuat pelaporan maintenance yang dilakukan oleh Bagian Administration. Teknisi bertugas untuk mengalokasikan pekerjaan maintenance dan membuat pelaporan maintenance.

Terdapat enam class diagram untuk sistem yang sedang berjalan yang ditunjukkan pada Gambar 2 yaitu Ruangan yang berisi data ruangan tempat aset, Aset yang berisi data aset, Tipe Aset yang berisi data tipe-tipe dari aset, Karyawan yang berisi informasi karyawan, Surat Perintah Kerja berisi informasi surat perintah kerja untuk teknisi yang akan melakukan maintenance, dan Maintenance yang berisi data maintenance (siapa yang melakukan dan aset apa saja yang di-maintenance). Gambar 3 menunjukkan tahapan-tahapan proses bisnis dari sistem yang sedang berjalan untuk mengetahui setiap tindakan yang dilakukan yang dimodelkan dalam Activity Diagram.

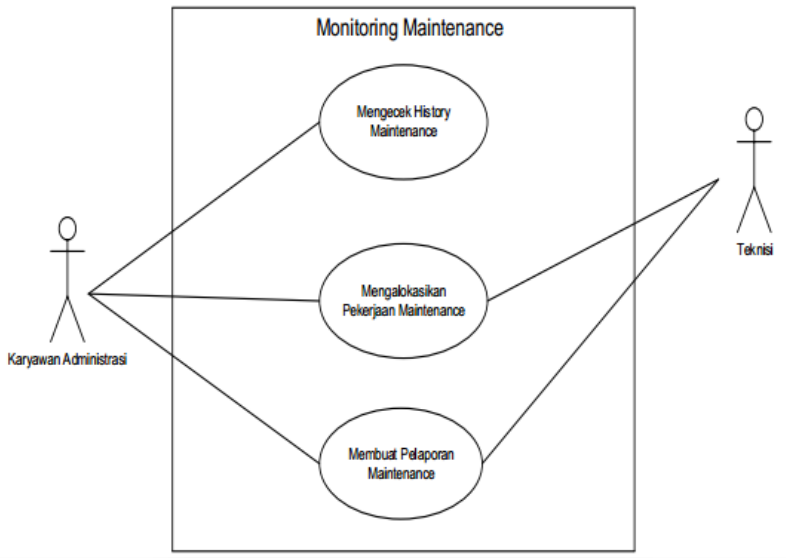

Gambar 1. Use Case Diagram Sistem Sedang Berjalan

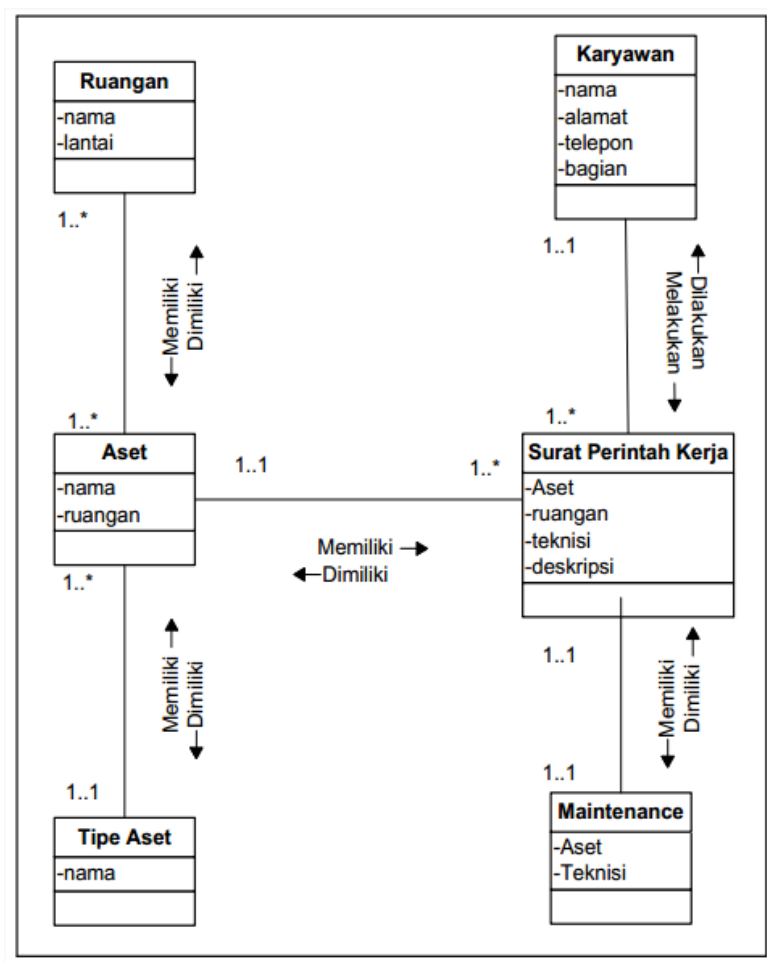

Gambar 2. Class Diagram Sistem Sedang Berjalan 


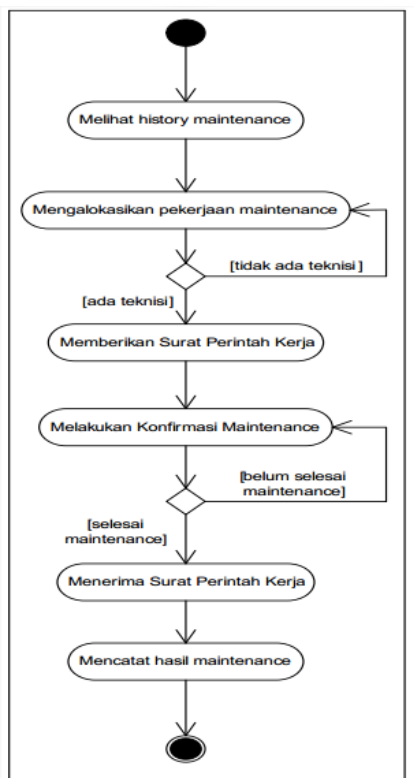

Gambar 3. Activity Diagram Sistem Sedang Berjalan

\section{User Design}

Daftar Aturan Bisnis dapat dilihat pada Tabel 1 .

Tabel 1. Daftar Aturan Bisnis

\begin{tabular}{|c|c|c|}
\hline No & Pengguna & Tanggung Jawab \\
\hline 1. & $\begin{array}{l}\text { Bagian } \\
\text { Administration }\end{array}$ & $\begin{array}{l}\text { a. Mengatur detail aset } \\
\text { b. Mengatur detail bagian } \\
\text { c. Mengatur detail jabatan } \\
\text { d. Mengatur detail } \\
\text { karyawan } \\
\text { e. Mengatur detail lantai } \\
\text { f. Mengatur detail ruangan } \\
\text { g. Mengatur detail kategori } \\
\text { aset } \\
\text { h. Mengatur detail } \\
\text { maintenance } \\
\text { i. Mengatur waktu } \\
\text { pengiriman SMS. }\end{array}$ \\
\hline 2. & Teknisi & $\begin{array}{l}\text { Melihat detail maintenance } \\
\text { sesuai teknisi }\end{array}$ \\
\hline
\end{tabular}

Gambaran tentang proses dan hubungan sistem baru dengan menggunakan Use Case Diagram yang ditunjukkan pada Gambar 4.

Use case diagram sistem yang baru mendeskripsikan kegiatan melakukan login/logout, melakukan manajemen karyawan, melakukan pengaturan lantai dan ruangan, melakukan manajemen aset, mengalokasikan pekerjaan maintenance, dan membuat laporan oleh Bagian Administration dan kegiatan melakukan login/logout, mengalokasikan pekerjaan maintenance dan membuat laporan yang dilakukan oleh Teknisi.

Class diagram digunakan untuk menggambarkan perbedaan yang mendasar antar class dan hubungan diantara class. Terdapat sembilan class pada gambar di bawah yaitu Ruangan, Lantai, Aset Ruangan, Aset, Tipe Aset, Karyawan, Jabatan, Bagian, dan Maintenance. High Level Class Diagram Sistem Baru ditunjukkan pada Gambar 5.

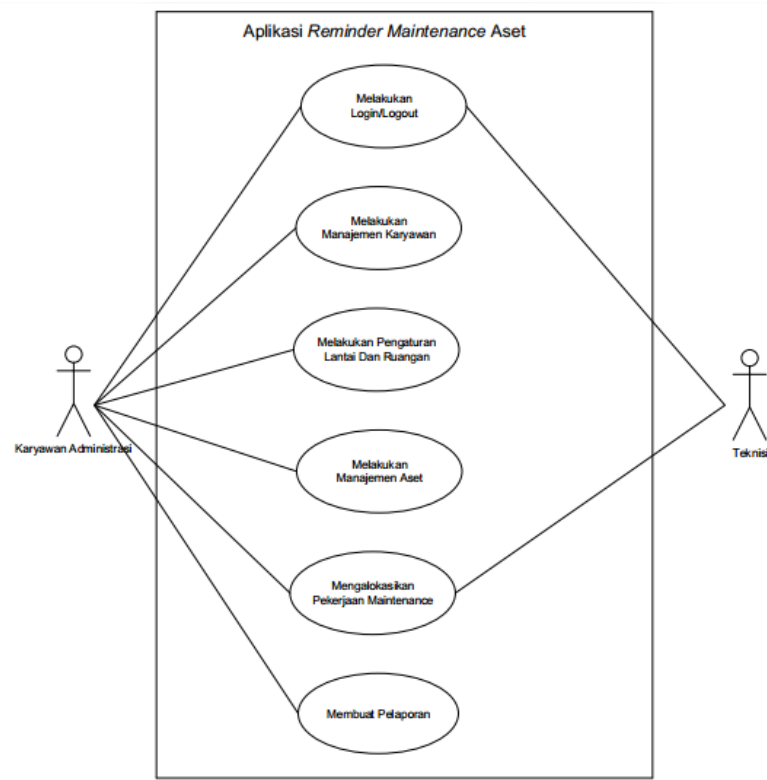

Gambar 4. Use Case Diagram Sistem Baru

Activity Diagram merupakan diagram yang menggambarkan aliran kerja atau workflow dan aktivitas dalam sebuah aplikasi. Untuk mengetahui setiap tindakan yang terjadi pada sebuah aplikasi, diperlukan penggambaran menggunakan diagram ini. Activity Diagram Sistem baru terbagi 2 (dua) yaitu Activity Diagram Bagian Administration yang ditunjukkan pada Gambar 6 dan Activity Diagram Teknisi yang ditunjukkan pada Gambar 7. 


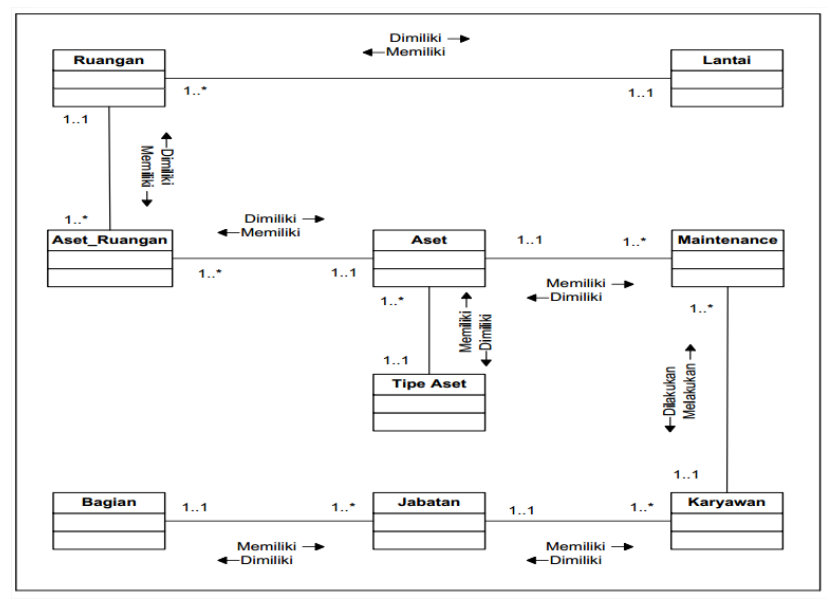

Gambar 5. High Level Class Diagram Sistem Baru

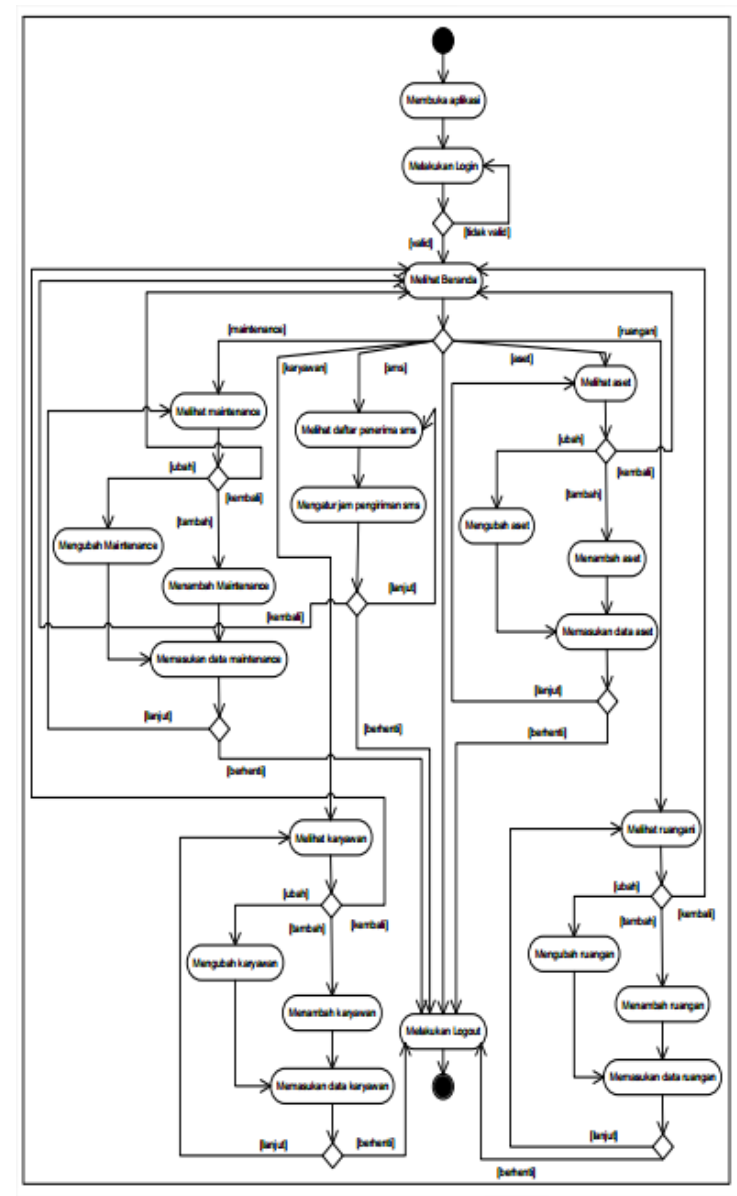

Gambar 6. Activity Diagram Sistem Baru Bagian Administration

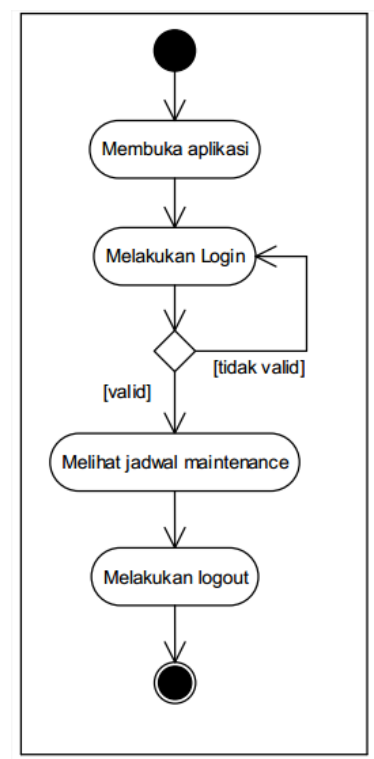

Gambar 7. Activity Diagram Sistem Baru Teknisi

Tampilan antar muka dari aplikasi reminder maintenance aset berbasis web berupa storyboard. Storyboard reminder ditunjukkan pada Gambar 8. Tujuan storyboard ini adalah untuk menampilkan aset yang sudah dekat waktunya untuk dilakukan maintenance. Fitur Aplikasi ini untuk menampilkan pemberitahuan aset mana yang harus segera di-maintenance kemudian mengalokasikan pekerjaan maintenance ke teknisi.

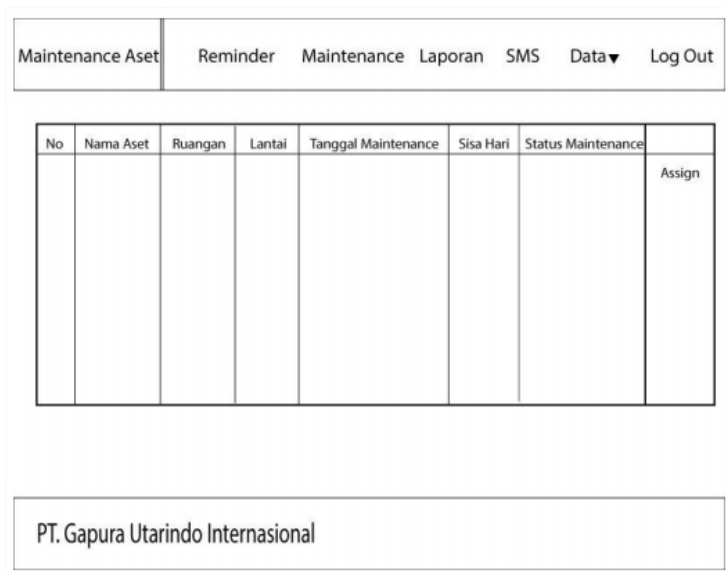

Gambar 8. Storyboard Reminder

Gambar 9 menunjukkan storyboard mengalokasikan pekerjaan maintenance. tujuan storyboard ini adalah untuk mengalokasikan pekerjaan maintenance 
kepada teknisi. Fitur aplikasi ini untuk menampilkan daftar teknisi untuk melakukan maintenance.
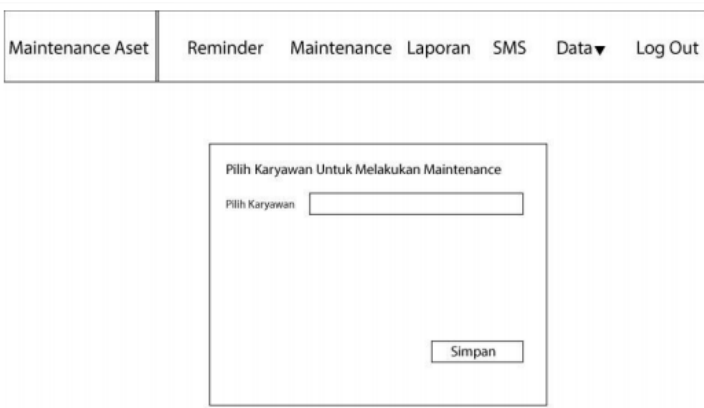

PT. Gapura Utarindo Internasional

Gambar 9. Storyboard Mengalokasikan Pekerjaan Maintenance

Gambar 10 menunjukkan storyboard maintenance. Tujuan storyboard ini adalah untuk menampilkan history maintenance. Fitur aplikasi ini untuk menampilkan data maintenance yang pernah dilakukan dan data maintenance yang sedang dilakukan dari aset.

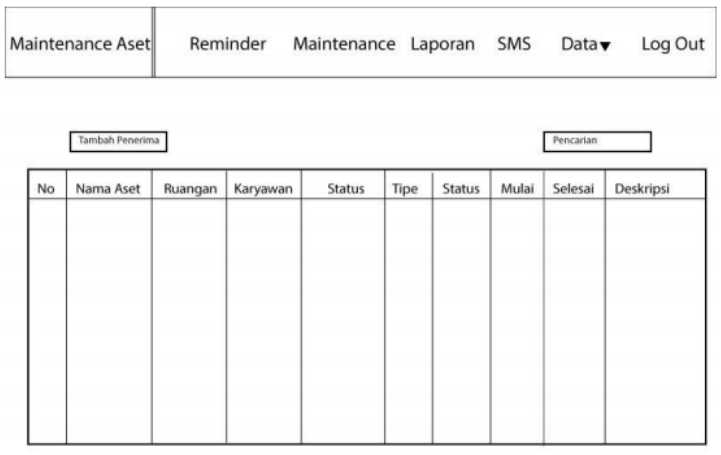

PT. Gapura Utarindo Internasional

Gambar 10. Storyboard Maintenance

Gambar 11 menunjukkan storyboard SMS. Tujuan dari storyboard ini adalah untuk menampilkan daftar penerima SMS notifikasi maintenance. Fitur aplikasi ini untuk menampilkan daftar penerima SMS berdasarkan tipe pengguna kemudian pengguna juga dapat mengatur jam untuk melakukan pengiriman SMS.

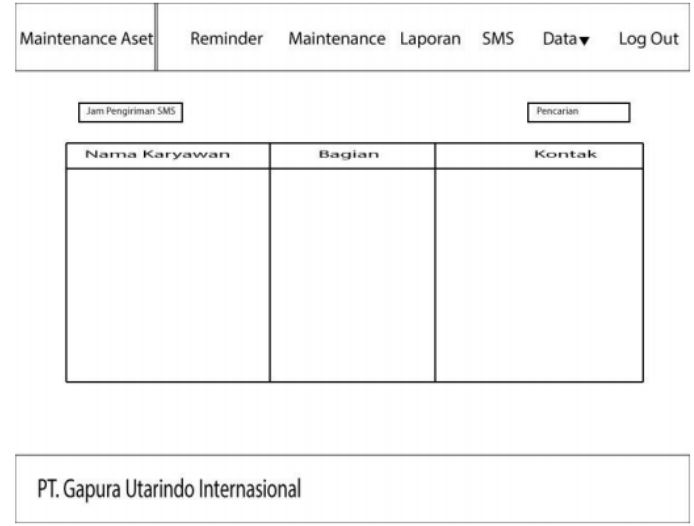

Gambar 11. Storyboard SMS

\section{Construction}

Spesifikasi Perangkat Keras dan Perangkat Lunak dalam pembangunan aplikasi ditunjukkan pada Tabel 2 dan Tabel 3.

Tabel 2. Spesifikasi Perangkat Keras

\begin{tabular}{|l|l|}
\hline \multicolumn{1}{|c|}{ Nama } & \multicolumn{1}{c|}{ Rekomendasi } \\
\hline Processor & $\begin{array}{l}\text { Intel Pentium Dual Core atau lebih } \\
\text { tinggi }\end{array}$ \\
\hline Memory & $2 \mathrm{~GB}$ atau lebih tinggi \\
\hline Harddisk & $500 \mathrm{~GB}$ \\
\hline Monitor & 14 inches \\
\hline Keyboard, Mouse & Standard \\
\hline
\end{tabular}

Tabel 3. Spesifikasi Perangkat Lunak

\begin{tabular}{|l|l|}
\hline \multicolumn{1}{|c|}{ Nama } & \multicolumn{1}{c|}{ Fungsi } \\
\hline $\begin{array}{l}\text { MySQL versi } \\
5.5 .27\end{array}$ & $\begin{array}{l}\text { Perangkat lunak untuk manajemen basis } \\
\text { data }\end{array}$ \\
\hline $\begin{array}{l}\text { Adobe } \\
\text { Photoshop }\end{array}$ & $\begin{array}{l}\text { Image Editing untuk merancang tampilan } \\
\text { aplikasi }\end{array}$ \\
\hline $\begin{array}{l}\text { Mozilla } \\
\text { Firefox }\end{array}$ & $\begin{array}{l}\text { Perangkat lunak untuk menjalankan } \\
\text { aplikasi }\end{array}$ \\
\hline $\begin{array}{l}\text { Microsoft } \\
\text { Visio }\end{array}$ & Perangkat lunak untuk merancang diagram \\
\hline Sublime Text 3 & $\begin{array}{l}\text { Text editor untuk membuat aplikasi dengan } \\
\text { bahasa pemrograman yang digunakan }\end{array}$ \\
\hline $\begin{array}{l}\text { PHP } \\
5.4 .7\end{array}$ & $\begin{array}{l}\text { Bahasa pemrograman yang digunakan } \\
\text { untuk membangun aplikasi }\end{array}$ \\
\hline
\end{tabular}

Basis data Aplikasi Reminder Maintenance Aset Berbasis Web dibuat dengan menggunakan DBMS MySQL. Tampilan tabel-tabel yang ada dalam basis data ditunjukkan pada Gambar 12, Gambar 13, Gambar 14, Gambar 15, Gambar 16, Gambar 17, Gambar 18, Gambar 19, dan Gambar 20. 


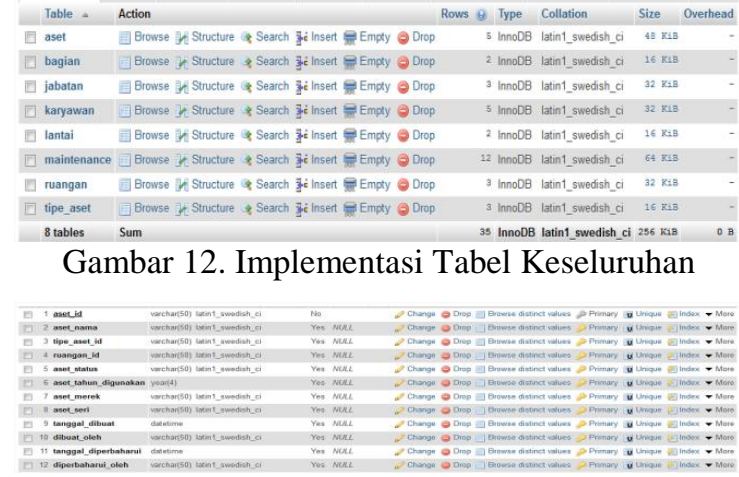

Gambar 13. Implementasi Tabel Aset

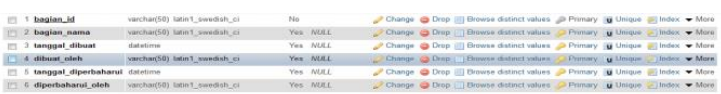

Gambar 14. Implementasi Tabel Bagian

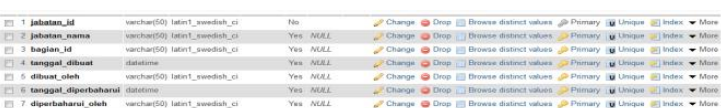

Gambar 15. Implementasi Tabel Jabatan

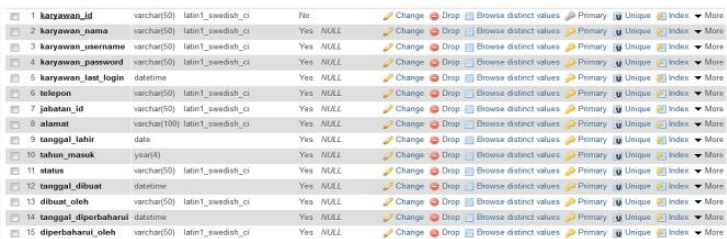

Gambar 16. Implementasi Tabel Karyawan

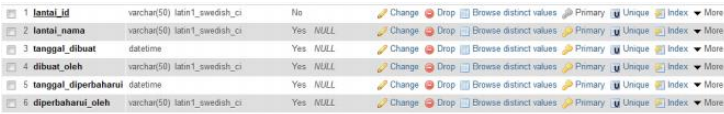

Gambar 17. Implementasi Tabel Lantai

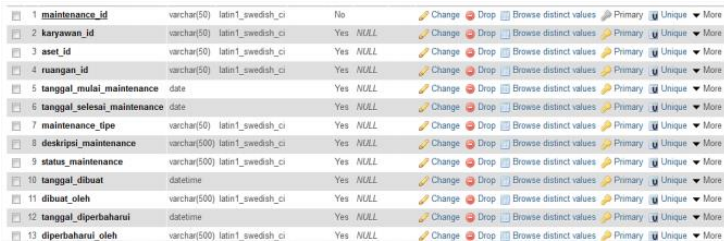

Gambar 18. Implementasi Tabel Maintenance

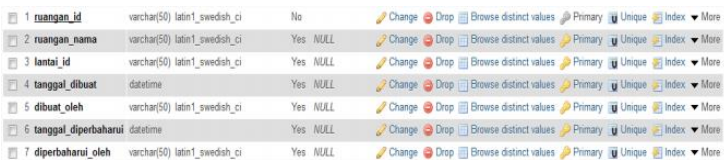

Gambar 19. Implementasi Tabel Ruangan

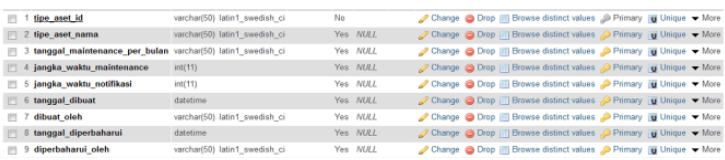

Gambar 20. Implementasi Tabel Tipe Aset

Tampilan halaman aplikasi dapat dilihat pada Gambar 21, Gambar 22, Gambar 23, dan Gambar 24.

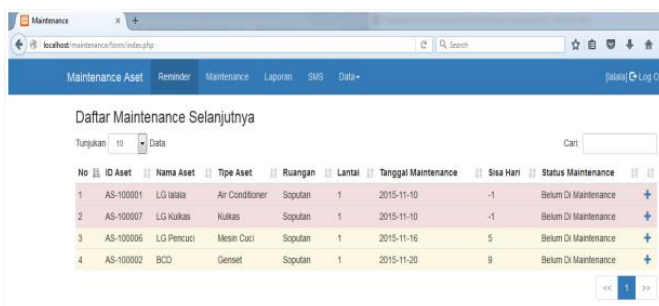

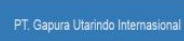

Gambar 21. Tampilan Halaman Reminder

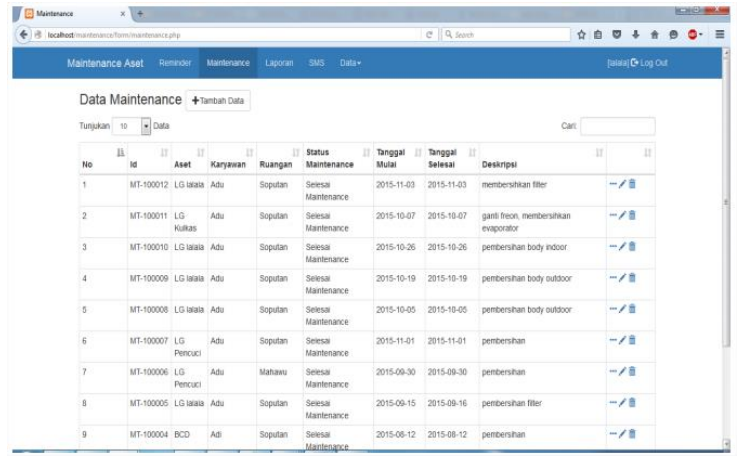

Gambar 22. Tampilan Halaman Maintenance
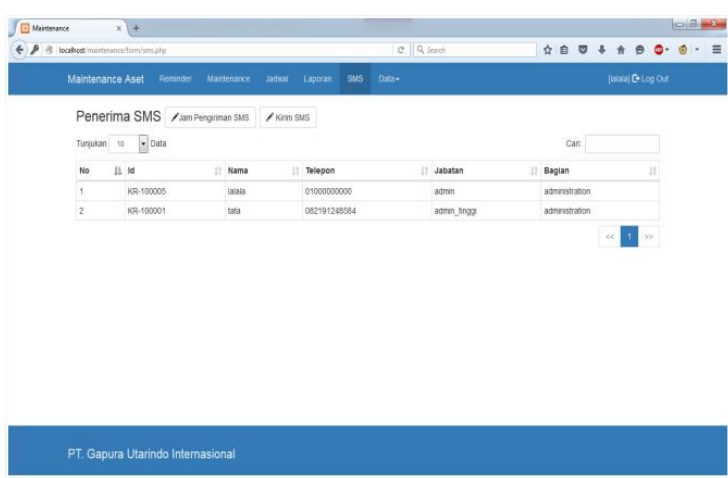

Gambar 23. Tampilan Halaman SMS

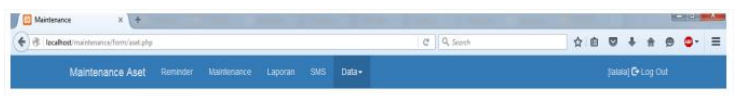

Data Aset tratrent now

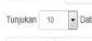

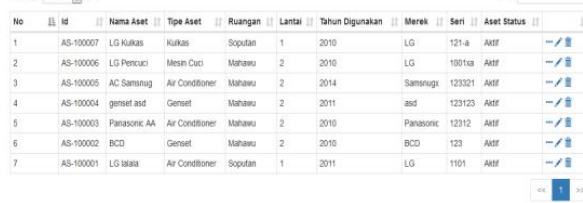

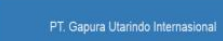

Gambar 24. Tampilan Halaman Aset 
Kriteria pengujian pada aplikasi ini adalah sebagai berikut:

1. Kemudahan menggunakan aplikasi

2. Semua fitur berjalan sesuai tujuan dan tidak terjadi error

3. Kebutuhan pengguna dan aplikasi telah terpenuhi

4. Kesiapan aplikasi untuk digunakan

Pelaksanaan pengujian pada Tabel 4 dilakukan untuk mengetahui hasil yang terjadi sesuai dengan yang diharapkan.

Tabel 4. Test Plan

\begin{tabular}{|c|c|c|c|}
\hline No & Description & $\begin{array}{l}\text { Expectation } \\
\text { Result }\end{array}$ & Actual Result \\
\hline \multicolumn{4}{|c|}{ Tes Web Browser dari segi antar muka } \\
\hline 1 & $\begin{array}{l}\text { Mozilla Firefox } \\
43.0 \mathrm{~b} 1\end{array}$ & $\begin{array}{l}\text { Aplikasi } \\
\text { akan berjalan } \\
\text { normal }\end{array}$ & $\begin{array}{l}\text { Aplikasi } \\
\text { berjalan } \\
\text { normal }\end{array}$ \\
\hline 2 & $\begin{array}{l}\text { Google Chrome } \\
46.0 .2490 .90 .8 \\
0\end{array}$ & $\begin{array}{l}\text { Aplikasi } \\
\text { akan berjalan } \\
\text { normal }\end{array}$ & $\begin{array}{l}\text { Aplikasi } \\
\text { berjalan } \\
\text { normal }\end{array}$ \\
\hline 3 & $\begin{array}{l}\text { Internet } \\
\text { Explorer } \\
8.0 .7601 .17514\end{array}$ & $\begin{array}{l}\text { Aplikasi } \\
\text { akan berjalan } \\
\text { normal }\end{array}$ & $\begin{array}{l}\text { Tampilan } \\
\text { menu } \\
\text { aplikasi } \\
\text { berubah, dan } \\
\text { lebih lama } \\
\text { diakses }\end{array}$ \\
\hline \multicolumn{4}{|c|}{ Menu utama Aplikasi } \\
\hline 1 & $\begin{array}{l}\text { Memasukkan } \\
\text { login yang } \\
\text { benar }\end{array}$ & $\begin{array}{l}\text { Aplikasi } \\
\text { akan } \\
\text { memvalidasi } \\
\text { username } \\
\text { dan } \\
\text { password, } \\
\text { kemudian } \\
\text { memberikan } \\
\text { hak akses } \\
\text { sesuai tipe } \\
\text { pengguna }\end{array}$ & $\begin{array}{l}\text { Aplikasi } \\
\text { akan } \\
\text { memvalidasi } \\
\text { username } \\
\text { dan } \\
\text { password, } \\
\text { kemudian } \\
\text { memberikan } \\
\text { hak akses } \\
\text { sesuai tipe } \\
\text { pengguna }\end{array}$ \\
\hline 2 & $\begin{array}{l}\text { Memasukkan } \\
\text { login yang salah }\end{array}$ & $\begin{array}{l}\text { Aplikasi } \\
\text { akan } \\
\text { memvalidasi } \\
\text { masukan dan } \\
\text { akan } \\
\text { menampilkan } \\
\text { pesan } \\
\text { kesalahan }\end{array}$ & $\begin{array}{l}\text { Aplikasi } \\
\text { akan } \\
\text { memvalidasi } \\
\text { masukan dan } \\
\text { akan } \\
\text { menampilkan } \\
\text { pesan } \\
\text { kesalahan }\end{array}$ \\
\hline \multicolumn{4}{|c|}{ Menu Bagian Administration } \\
\hline 1 & $\begin{array}{l}\text { Memilih salah } \\
\text { satu menu pada } \\
\text { menubar atau } \\
\text { menu yang ada } \\
\text { pada sub menu }\end{array}$ & $\begin{array}{l}\text { Menampilka } \\
\mathrm{n} \text { halaman } \\
\text { dari menu } \\
\text { yang dipilih }\end{array}$ & $\begin{array}{l}\text { Menampilka } \\
\mathrm{n} \text { halaman } \\
\text { dari menu } \\
\text { yang dipilih }\end{array}$ \\
\hline 2 & $\begin{array}{l}\text { Memasukkan } \\
\text { data } \quad \text { sesuai }\end{array}$ & $\begin{array}{l}\text { Melakukan } \\
\text { validasi } \\
\text { terhadap data }\end{array}$ & $\begin{array}{l}\text { Melakukan } \\
\text { validasi } \\
\text { terhadap data }\end{array}$ \\
\hline
\end{tabular}

\begin{tabular}{|c|c|c|c|}
\hline & $\begin{array}{l}\text { menu yang } \\
\text { dipilih }\end{array}$ & $\begin{array}{l}\text { setelah itu } \\
\text { melakukan } \\
\text { penyimpanan } \\
\text { ke database }\end{array}$ & $\begin{array}{l}\text { setelah itu } \\
\text { melakukan } \\
\text { penyimpanan } \\
\text { ke database }\end{array}$ \\
\hline 4 & Mengirim SMS & $\begin{array}{l}\text { Menentukan } \\
\text { jam } \\
\text { mengirim } \\
\text { SMS } \\
\text { reminder } \\
\text { kemudian } \\
\text { SMS akan } \\
\text { dikirim } \\
\text { setiap hari } \\
\text { sesuai jam } \\
\text { yang } \\
\text { ditentukan }\end{array}$ & $\begin{array}{l}\text { Menentukan } \\
\text { jam } \\
\text { mengirim } \\
\text { SMS } \\
\text { reminder } \\
\text { kemudian } \\
\text { SMS akan } \\
\text { dikirim } \\
\text { setiap hari } \\
\text { sesuai jam } \\
\text { yang } \\
\text { ditentukan }\end{array}$ \\
\hline 5 & $\begin{array}{l}\text { Melakukan } \\
\text { pencarian }\end{array}$ & $\begin{array}{l}\text { Aplikasi } \\
\text { akan } \\
\text { menampilkan } \\
\text { data sesuai } \\
\text { dengan kata } \\
\text { yang } \\
\text { dimasukkan }\end{array}$ & $\begin{array}{l}\text { Aplikasi } \\
\text { akan } \\
\text { menampilkan } \\
\text { data sesuai } \\
\text { dengan kata } \\
\text { yang } \\
\text { dimasukkan }\end{array}$ \\
\hline \multicolumn{4}{|c|}{ Menu Utama Teknisi } \\
\hline 1 & $\begin{array}{l}\text { Melakukan } \\
\text { Pencarian } \\
\text { Maintenance }\end{array}$ & $\begin{array}{l}\text { Aplikasi } \\
\text { akan mencari } \\
\text { dan } \\
\text { menampilkan } \\
\text { data } \\
\text { maintenance } \\
\text { sesuai } \\
\text { dengan kata } \\
\text { yang } \\
\text { dimasukkan }\end{array}$ & $\begin{array}{l}\text { Aplikasi } \\
\text { akan mencari } \\
\text { dan } \\
\text { menampilkan } \\
\text { data } \\
\text { maintenance } \\
\text { sesuai } \\
\text { dengan kata } \\
\text { yang } \\
\text { dimasukkan }\end{array}$ \\
\hline
\end{tabular}

Secara ringkas, hasil pengujian aplikasi adalah sebagai berikut:

1. Aplikasi dapat berjalan cukup baik dan memenuhi kebutuhan pengguna

2. Mudah digunakan karena tampilan cukup jelas dan dapat dimengerti

3. Fungsi pengolahan data seperti fungsi tambah, dan ubah sudah berjalan dengan baik

4. Dari segi web browser yang berbedabeda antarmuka aplikasi terlihat menarik dan dapat berjalan dengan baik dengan menggunakan Mozilla Firefox atau Google Chrome dibandingkan dengan Internet Explorer. 


\section{E. KESIMPULAN}

Berdasarkan hasil penelitian, maka dapat disimpulkan:

1. Aplikasi ini dapat memberikan pemberitahuan aset apa yang sudah harus dilakukan maintenance.

2. Aplikasi ini dapat menampilkan laporan history maintenance aset

3. Aplikasi ini dapat memberikan kemudahan dalam melakukan pencarian history maintenance dari aset

Saran yang berkaitan dengan pengembangan aplikasi selanjutnya adalah:

1. Aplikasi ini dapat dikembangkan dengan membuat auto reply tentang informasi maintenance jika karyawan mengirim SMS dengan format tertentu

2. Aplikasi ini dapat dikembangkan untuk mengalokasikan pekerjaan maintenance secara otomatis agar pembagian maintenance diantara teknisi merata.

\section{F. DAFTAR PUSTAKA}

Anhar. 2010. PHP \& MySQL Secara Otodidak. Jakarta: Mediakita.

Dewa, R. 2012. Setiap Hari Menjadi Magnet \& Mesin Uang. Jakarta: Visimedia.

Ginanjar, T. 2014. Rahasia Membangun Website Toko Online Berpenghasilan Jutaan Rupiah. Bogor: IFA Media.

Junindar. 2008. Panduan Lengkap Menjadi Programmer. Jakarta: Mediakita.

Mahler, A., Sabirin, N. 2008. Dari Grasber Sampai Amamapare Proses Penambangan Tembaga \& Emas Mulai Hulu Hingga Hilir. Jakarta: Gramedia.
Nurhayati, Y. 2015. Pembukuan Wajib Untuk Bisnis. Jakarta: Raih Asa Sukses.

Sawena, Y., Suryati, H., Mawlan, S. 2014. Sistem Informasi Akademik pada SMP Karya Dharma Bhakti 2 Palembang. Avaiable online: http://eprints.mdp.ac.id/1053/.

Syamsuri, M. 2010. Kamus pintar Memilih Kata Bahasa Inggris. Jakarta: PT Gramedia Pustaka Utama.

Solichin, A. 2010. MySQL 5: Dari Pemula Hingga Mahir. Jakarta: Universitas Budi Luhur.

Setiawan, A., Endrawan, DTP., Fathoni, R., Budi, SP. 2011. Rapid Application Development. Avaiable online: https://mazadie.files.wordpress.com/ 2012/01/rapid-applicationdevelopment.pdf.

Thompson, R. 2013. Automotive Maintenance \& Light Repair. Singapore: Cengage Learning.

Ukar, K. 2006. SES: Microsoft Word. Jakarta: Elex Media Komputindo. 